\title{
Aromatherapy sebagai alternatif untuk menurunkan tingkat stres menghadapi ujian pada mahasiswa Universitas Muhammadiyah Kalimantan Timur
}

\author{
Desita Dyah Damayanti ${ }^{1}$, Dian Putriana ${ }^{1}$, Citra Mutiara Dewi ${ }^{1}$, dan Almadian Septiana \\ Putri $^{1}$
}

\begin{abstract}
Stress is one of the daily psychological conditions that are now difficult to avoid by humans. Stress arises because of the inability of individuals to complete the burden or pressure, especially by students in the scope of education. Stress in the educational environment that cannot be managed properly will certainly have a negative impact, for example decreased learning motivation and decreased academic achievement results. This service was carried out with the aim of seeing the effect of the intervention of giving aromatherapy in reducing the level of stress experienced by students in the educational environment of the Muhammadiyah University of East Kalimantan. This service uses a quasi-experimental method that provides treatment or intervention to one group of two existing service groups. The number of subjects who participated in this service amounted to 18 students who were selected by purposive sampling technique from the pre-test results with the stress category below normal. Before and after the treatment, the respondent's stress level was measured using the Depression Anxiety Stress Scale (DASS) questionnaire. Aromatherapy intervention was given in the form of oil dissolved in mineral water and turned into steam with the help of a diffuser until the steam produced was able to spread and give a lavender aroma sensation throughout. The results showed that the aromatherapy intervention had a reduction in stress levels but it was not significant. Of the nine people there were five people who experienced a decrease while the other four did not change. The pre-test and post-test data were analyzed by adding up the total DASS item scores and generalizing by the norm of the test instrument category.
\end{abstract}

\section{Keywords}

academic stress, aromatherapy, stress intervention, university student

\section{Pendahuluan}

Perubahan tekanan sosial kehidupan saat ini tentu memberikan efek besar dalam kesehatan fisik maupun mental. Stres merupakan salah satu kondisi psikologis sehari-hari yang kini sulit dihindari oleh manusia. Hal ini tentu didukung oleh beberapa faktor, contohnya modernisasi, industrialisasi serta kemajuan teknologi yang sangat pesat dan cepat sehingga mempengaruhi nilai-nilai moral dan gaya hidup seseorang. Faktor-faktor tersebut kemudian memaksa manusia untuk terus maju seiring dengan zaman dan beradaptasi dengan baik, namun ketika seseorang tidak mampu melakukannya maka muncul tekanan-tekanan yang kemudian disebut dengan stres.

Survei dengan cara menyebarkan kuesioner untuk mengukur tingkat stres yang dialami mahasiswa di lokasi mitra dilakukan penulis untuk melihat urgensi dilakukannya intervensi stres untuk mahasiswa terutama saat menghadapi ujian di tengah masa pandemi covid-19. Sejumlah 107 orang mahasiswa di lokasi mitra mengisi kuesioner tersebut dan diporeh hasil statistik sebesar 58\% mahasiswa mengalami kondisi stres atau sejumlah 62 orang. Hasil tersebut yang kemudian menjadi landasan penulis untuk kemudian memberikan intervensi stres khususnya di lingkungan akademik.

Sarafino et al. (2011) menjelaskan definisi dari stres yaitu sebagai kondisi yang disebabkan oleh interaksi antara individu dengan lingkungan, kemudian interaksi tersebut menimbulkan jarak antara tuntutan-tuntutan yang berasal dari situasi yang bersumber pada sistem biologis, psikologis dan sosial seseorang. Definisi stres juga dijelaskan oleh Robbins \& Coulter (2010) yaitu suatu kondisi yang menekan keadaan psikis seseorang dalam mencapai suatu kesempatan dimana untuk mencapai hal tersebut terdapat batasan atau halangan. Stres bisa berasal

\footnotetext{
${ }^{1}$ Universitas Muhammadiyah Kalimantan Timur

Korespondensi:

Desita Dyah Damayanti, Fakultas Psikologi Universitas Muhammadiyah Kalimantan Timur

Email: ddd822@umkt.ac.id
} 
dari individu, lingkungan keluarga, lingkungan tempat tinggal, lingkungan kerja bahkan lingkungan pendidikan.

Adiesisa et al. (2016) mengatakan bahwa stres merupakan salah satu konsekuensi dari kehidupan modern saat ini. Brunton et al. (2008) mengkategorisasikan sumber stres yaitu akademik, keuangan, hal-hal yang berkaitan dengan waktu, kesehatan dan self-imposed. Perguruan tinggi termasuk dalam situasi lingkungan pendidikan dimana banyak situasi yang terjadi dan kemudian menimbulkan tuntutan terhadap individu-individu di dalamnya. Tuntutan tersebut jika dapat dihadapi dengan baik maka stres yang timbul tidak akan mempengaruhi proses pendidikan yang dijalani, namun bila tuntutan tersebut tidak mampu dihadapi dengan baik salah satu konsekuensi yang harus dihadapi ialah terhambatnya proses pendidikan dengan masalah-masalah yang timbul dari tuntutan tersebut.

Sumber stres pada akademik dapat berasal dari proses belajar mengajar yang kemudian dapat dispesifikkan seperti tekanan untuk naik tingkat, lama waktu belajar, intensitas banyaknya tugas, keputusan menentukan jurusan, kecemasan dalam menghadapi ujian dan manajemen waktu yang kurang baik (Desmita, 2010). Stres di lingkungan pendidikan yang tidak dapat dikelola dengan baik tentu akan memberikan dampak negatif, misalnya menurunnya motivasi belajar, menurunnya hasil prestasi akademik, meningkatnya ketidakhadiran di kelas, sulit konsentrasi, kecemasan berlebih saat menghadapi ujian serta enggan menghadapi dosen atau mata kuliah tertentu (Nurdini, 2009).

Berdasarkan penjelasan di atas yang menjadi alasan penulis memilih Universitas Muhammadiyah Kalimantan Timur sebagai tempat penelitian adalah karena beberapa dari mahasiswa mengeluhkan tekanan yang berlebih di dalam proses belajar mengajar di masa pandemi covid19. Pada masa proses belajar mengajar dilakukan secara online, sehingga mahasiswa harus dapat beradaptasi dengan keadaan tersebut. Hal ini juga sangat berpengaruh pada tingkat stres mahasiswa saat menghadapi ujian. Namun Universitas Muhammadiyah Kalimantan Timur yang dikenal memiliki slogan IT-based mengharapkan agar selayaknya seluruh mahasiswa dapat beradaptasi dengan proses pembelajaran online ini. Oleh karena itu penulis akhirnya mencari alternatif cara untuk mengurangi masalah stres dari mahasiswa agar mahasiswa lebih mampu menjalani kehidupan perkuliahan dengan baik lagi.

Kozier et al. (2010) mengatakan bahwa ada beberapa cara yang dapat dilakukan untuk menurunkan stres, misalnya yoga, relaksasi nafas, terapi tertawa dan aromaterapi. Hal ini kemudian didukung dengan hasil penelitian sebelumnya yang dilakukan oleh Sya'diyah et al. (2017) bahwa aromaterapi lavender memiliki pengaruh terhadap menurunnya tingkat stres yang dimiliki oleh lansia di Panti Werdha Anugrah Surabaya. Perez (Anggraini, 2015) menjelaskan bahwa aromaterapi lavender dapat mempengaruhi limbic system di otak yang merupakan pusat emosi, suasana hati atau mood, dan memori untuk menghasilkan bahan neurohormon endorphin dan encephalon, yang bersifat sebagai penghilang rasa sakit dan hormone serotonin yang berefek menghilangkan ketegangan atau stres.

Aromaterapi yang berasal dari tumbuhan aromatik yang telah dimanfaatkan manusia sebagai metode pengobatan dengan media wangi-wangian (Sharma, 2009). Seiring perkembangan zaman, aromaterapi kemudian diproduksi dengan berbagai bentuk, misalnya minyak esensial, dupa, oil, garam, minyak pijat dan sabun. Berdasarkan bentukbentuknya aromaterapi kemudian memiliki manfaatnya masing-masing yaitu sebagai pewangi ruangan, aroma minyak saat dipijat, sebagai campuran air saat mandi dan sebagai wewangian badan setelah mandi.

Berdasarkan pemaparan di atas, penulis kemudian tertarik untuk mengetahui lebih jauh apakah aromaterapi juga mampu menurunkan tingkat stres yang dialami oleh mahasiswa di lingkungan pendidikan Universitas Muhammadiyah Kalimantan Timur.

Rumusan masalah dalam penelitian ini yakni apakah aromaterapi mampu memberikan efek penurunan tingkat stres seperti aromaterapi lavender yang berbentuk pewangi ruangan. Selain itu penulis juga ingin mengetahui apakah pemberian terapi ini juga mampu memberikan efek pada peningkatan fokus belajar mahasiswa. Untuk tempo jangka panjang, penulis berharap terapi ini juga mampu bermanfaat untuk masyarakat luas sebagai alternatif terapi yang dapat dilakukan untuk menurunkan tingkat stres yang dialami sehari-hari.

penelitian ini memiliki dua tujuan yakni secara empiris dan teoritis. Tujuan empiris dari penelitian ini yaitu ingin mengetahui pengaruh dari oil aromaterapi sebagai media pengembangan terapi menurunkan stres khususnya di lingkungan pendidikan perguruan tinggi yang harapannya jika terapi ini memberikan pengaruh terhadap tingkat stres maka terapi ini seterusnya dapat diaplikasikan di lingkungan pendidikan khususnya dalam proses belajar mengajar serta disosialisasikan kepada masyarakat umum sebagai terapi yang dapat dilakukan untuk menurunkan tingkat stres yang dimiliki.

Stres adalah kondisi seseorang yang mengalami tekanan terhadap beberapa tuntutan dan tekanan hidup yang sering berubah ketika otak sedang menghadapi sebuah situasi dimana seseorang mengalami tuntutan/tekanan seseorang akan mengalami stres karena merasa dirinya sedang merasakan sebuah tekanan terhadap lingkungannya. Seseorang yang mengalami stres biasanya merasakan tidak nyaman seperti ingin mengerjakan segalanya dengan cepat, ingatan melemah, munculnya ketidakmampuan berkonsentrasi, tidak mampu melakukan tugas yang sudah dimulai serta kehilangan semangat.

Menurut Patel et al. (1985) stres tidak selalu bersifat negatif pada dasarnya stres merupakan respon-respon tertentu pada tubuh terhadap adanya sebuah tekanan dari luar kemampuan coping personal dan kemampuan lingkungan untuk memberi sebuah dukungan dari hasil 
interaksi tadi akan menghasilkan persepsi terhadap stres. Ketika stres telah dipersepsikan secara positif dan dapat memberikan motivasi terhadap seseorang untuk lebih percaya diri.

Hal serupa juga dijelaskan oleh Cranweld-ward (Anggraini, 2015) bahwa stres adalah reaksi fisiologis dan psikologis yang terjadi kepada seseorang yang sedang merasakan ketidak seimbangan terhadap beban yang dihadapi dengan kemampuan untuk mengatasi beban itu sendiri. Sedangkan Korchin (Anggraini, 2015) menjelaskan stres tidak hanya berupa kondisi namun yang menekan baik dari keadaan fisik atau psikis seseorang.

Sarafino et al. (2011) mendefinisikan stres adalah kondisi yang terjadi karena adanya interaksi individu dengan lingkungan yang menyebabkan individu melihat ketidaksesuaian antara tuntutan fisik atau keadaan psikologis dengan tuntutan sosial. Corneli (Taylor, 2006) menyatakan bahwa stres merupakan gangguan yang dialami tubuh dan pikiran individu yang disebabkan oleh perubahan dan tuntutan kehidupan yang dipengaruhi oleh lingkungan maupun penampilan individu dalam lingkungan tersebut.

Ada dua aspek utama yang ditimbulkan seseorang yang mengalami stres yaitu aspek fisik dan aspek psikologis (Sarafino et al., 2011) yaitu: (1) Stres fisik, yakni aspek stres yang memiliki dampak menurunnya kondisi seseorang pada saat stres sehingga individu tersebut mengalami sakit pada bagian tubuh nya seperti sakit kepala, gangguan pencernaan dsb; (2) Stres psikis, yakni terdiri dari gejala kognisi, gejala emosi dan gejala tingkah laku. Gejala - gejala tersebut mempengaruhi kondisi psikologis seseorang dalam membuat kondisi psikologisnya berubah menjadi negatif, seperti hal nya mengalami penurunan daya ingat, merasa sedih secara berlebihan dan tiba-tiba, dan cenderung sering melakukan penundaan pekerjaan. Hal demikian juga dipengaruhi oleh berat atau ringannya stres yang dialami oleh seseorang. Aspek-aspek stres berdasarkan teori tersebut menjelaskan bahwa adanya keterkaitan antara seseorang yang mengalami stres dengan perubahan keadaan fisik dan psikologis.

Faktor-faktor yang memicu stres menurut Yusuf (2006) dapat diklasifikasikan kedalam beberapa kelompok yakni: (1) Stresor fisik-biologis, seperti adanya penyakit yang sulit untuk disembuhkan, cacat fisik adanya ketidak berfungsian nya salah satu organ tubuh, paras wajah yang kurang cantik atau tampan, serta postur tubuh yang menurut individu kurang ideal (seperti terlalu gemuk atau terlalu pendek); (2) Stresor psikologi, yakni seperti adanya negative thinking atau berburuk sangka yang berlebihan, frustasi (adanya kekecewaan yang disebabkan oleh gagalnya mendapatkan sesuatu yang diinginkan, penyakit hati seperti iri dengki dan berniat untuk selalu membalas dendam, sikap bermusuhan, memiliki kecemburuan yang besar, konflik pribadi dan keinginan di luar kemampuan diri.

Stresor sosial, yakni seperti keadaan individu yang berdampingan langsung dengan iklim kehidupan keluarga.
Adanya hubungan antar keluarga yang kurang harmonis, perceraian, adanya suami atau istri yang berselingkuh, orang yang dicintai meninggal dunia, membantah orangtua dan membolos sekolah, penyalahgunaan obat-obatan, tingkat ekonomi keluarga rendah dan adanya anggota keluarga yang mengalami gangguan jiwa. Adapun faktor pekerjaan yakni adanya kesulitan mendapatkan pekerjaan, putus hubungan kerja, serta penghasilan yang tidak sesuai dengan tuntutan kebutuhan. Serta adanya faktor lingkungan yakni seperti adanya pencurian, perampokan (maraknya kriminalitas), adanya tawuran antar kelompok baik pelajar maupun warga masyarakat, minimnya fasilitas air bersih, kemarau panjang, udara sangat panas atau dingin, kebutuhan pokok yang mahal, polusi udara dan suara bising, lingkungan kotor dan daerah perumahan yang buruk, kehidupan politik dan ekonomi yang tidak stabil.

Setiap individu memiliki kemampuan dalam bertahan menghadapi stres yang dialami sehingga tidak mempengaruhi terganggunya kepribadian individu tersebut. Tiap individu memiliki tingkat toleransi yang berbeda. Untuk orang yang berkepribadian lemah maka akan memunculkan perilaku abnormal meskipun hanya dihadapkan dengan stres kecil. Begitupun sebaliknya, individu yang memiliki kepribadian yang kuat akan mampu mengatasi kondisinya walaupun dihadapkan dengan stres yang ego involved (Ardani, 2013).

Penelitian Ross et al. (1999) dilakukan di beberapa universitas di Amerika Utara untuk melihat seberapa besar tingkat prevalensi stres yang dialami oleh mahasiswa. Dari 100 partisipan yang dilibatkan di dalam penelitian ini diperoleh $38 \%$ prevalensi stres terjadi pada mahasiswa karena tekanan pendidikan di universitas. Selain itu jugaFirth (2011) melakukan penelitian serupa yang melibatkan 165 partisipan dan menunjukkan prevalensi stres yang terjadi kepada mahasiswa sebesar 31,2\%. Selanjutnya, penelitian yang dilakukan oleh Sangwin (2016), penelitian ini melibatkan 161 mahasiswa di tiga universitas di Pakistan dan hasilnya menunjukkan bahwa prevalensi stres terjadi pada 30,84\% dari mahasiswa yang terlibat dalam penelitian. Berdasarkan ketiga hasil penelitian sebelumnya dapat ditarik kesimpulan bahwa stres masih rentan terjadi di lingkungan pendidikan yang subjeknya didominasi oleh mahasiswa yang memiliki banyak tuntutan dan tekanan di perguruan tinggi.

Terapi aromaterapi untuk menurunkan stres sebelumnya juga pernah diteliti oleh Sya'diyah et al. (2017) terhadap lansia di Panti Werdha Anugrah Surabaya. Hasil penelitian menunjukkan adanya penurunan jumlah responden yang mengalami stres sesuai dengan kategori tingkatannya masing-masing berdasarkan pengukuran pre-test. penelitian serupa juga telah dilakukan oleh Widayani et al. (2016) yaitu pengaruh aromaterapi lavender terhadap penurunan tingkat stres saat penyusunan skripsi pada mahasiswa S1 keperawatan Stikes An Nur Purwodadi. Hasil penelitian ini menunjukkan bahwa adanya pengaruh aromaterapi dupa lavender terhadap penurunan tingkat stres saat penyusunan skripsi. penelitian 
yang memanfaatkan terapi aromaterapi di lingkungan pendidikan juga dilakukan oleh Anggraini (2015) yang melibatkan mahasiswa tingkat akhir di S1 keperawatan sebagai responden penelitian. Hasil penelitian tersebut ialah adanya pengaruh aromaterapi lavender terhadap stres pada mahasiswa tingkat akhir di S1 keperawatan.

Berdasarkan uraian penelitian sebelumnya maka penulis tertarik untuk melihat apakah terapi aromaterapi untuk menurunkan tingkat stres juga dapat diterapkan pada mahasiswa UMKT yang akan menghadapi ujian. Penulis juga ingin melihat apakah terapi ini juga dapat menjadi salah satu intervensi untuk menurunkan tingkat stres akademik mahasiswa. Selain itu hal lain yang dapat membedakan penelitian sebelumnya dengan penelitian ini adalah bentuk aromaterapi yang akan digunakan ialah oil dan wangi-wangiannya yang memberikan efek relaksasi seperti lavender.

\section{Metode}

\section{Desain Eksperimen}

Proses eksperimen dalam penelitian ini menggunakan metode kuasi eksperimen dimana mahasiswa sebagai mitra akan diberikan perlakuan dengan sengaja untuk melihat ada atau tidaknya pengaruh dari intervensi yang diberikan. Dalam pelaksanaan awal mahasiswa akan diukur tingkat stresnya menggunakan kuesioner DASS yang kemudian hasilnya dianalisis dengan cara mentotalkan jumlah skor yang diperoleh dan digeneralisasikan ke norma yang tersedia. Mahasiswa yang memiliki tingkat stres dibawah normal kemudian memiliki kesempatan untuk menjadi sampling dalam penelitian ini.

Setelah memperoleh sejumlah sampling yang dipilih dengan teknik purposive sampling mahasiswa dipisah menjadi dua kelompok, yaitu kelompok kontrol dan kelompok eksperimen yang salah satunya akan diberikan perlakuan sedangkan kelompok lainnya tidak diberikan perlakuan. Hal ini kemudian dilakukan untuk melihat seberapa besar pengaruh dari intervensi aroma terapi dalam menurunkan tingkat stres mahasiswa yang sedang mengerjakan ujian.

Intervensi dilakukan dengan melarutkan minyak aroma terapi lavender dengan air mineral dan diproses menjadi uap dengan bantuan alat diffuser sehingga aromanya akan menyebar keseluruh ruangan dan memberikan efek terapi suasana tenang dan nyaman. Setelah intervensi dilakukan penulis memberikan kembali kuesioner DASS untuk mengukur tingkat stres setelah pemberian intervensi baik itu di kelompok eksperimen maupun di kelompok kontrol yang tidak diberi perlakuan. Dari hasil pre-post test selanjutnya dianalisis apakah ada perbedaan tingkat stress sebelum dan sesudah diberikan perlakuan. Jika ditemukan adanya perbedaan maka terbukti bahwa intrervensi yang diberikan mampu memberikan pengaruh terhadap tingkat stres yang dimiliki mahasiswa.

\section{Instrumen penelitian}

Skala Depression Anxiety Stress Scale (DASS) digunakan untuk mengukur pra-test sebelum pemberian intervensi yang digunakan dalam melihat tingkat stres yang dimiliki oleh subyek penelitian. Selanjutnya, penulis memberikan intervensi berupa setting ruangan ujian dengan diberikan aromatherapy lavender yang menimbulkan efek relaksasi bagi subjek penelitian. Setelah selesai proses ujian yang dilakukan oleh subjek penelitian, penulis memberikan skala Depression Anxiety Stres Scale (DASS) untuk memperoleh data pasca-test yang hasilnya berupa tingkat stres setelah intervensi diberikan.

\section{Tahapan penelitian}

Untuk mendapatkan hasil dari penelitian ini, maka dibuat urutan kegiatan untuk memperoleh data sampai data tersebut dapat digunakan untuk membuat kesimpulan. Kegiatan ini dimulai dari proses pemeriksaaan dan penyediaan bahan, persiapan, pelaksanaan, evaluasi pelaksanaan dan analisis hasil penelitian serta pembahasan yang dibagi dalam lima tahap: (1) Pemeriksaan dan penyediaan bahan. Sebelum minyak aroma terapi digunakan, maka pada tahap ini dilakukan pemeriksaan kelayakan pada minyak jika dihirup oleh manusia dan mempersiapkan kuesioner DASS berupa kalimat-kalimat pernyataan. (2) Persiapan pemeriksaan. Tahap ini merupakan tahap persiapan penelitian di dalam setting tempat yang terdiri dari setting ruang praktikum individu mahasiswa psikologi, protokol kesehatan covid, dan minyak aroma terapi. (3) Pelaksanaan. Pada tahap ini minyak aroma terapi terdapat di dalam ruang penelitian dan kemudian mahasiswa mengerjakan ujian. (4) Evaluasi Pelaksanaan. Tahap ini, Mahasiswa Psikologi diminta untuk mengisi lembar kuesioner DASS sebagai pengukuran paska dari penggunaan minyak aroma terapi. (5) Analisis Hasil Penulisan dan Pembahasan. Dari hasil kuesioner pada tahap IV, kemudian dilakukan analisis data. Data yang diperoleh yakni dari dua kelas dengan jumlah populasi mahasiswa yang berbeda. Analisis tersebut merupakan pembahasan dari penelitian yang kemudian dapat ditarik beberapa kesimpulan penelitian.

\section{Prosedur penelitian}

Berikut merupakan prosedur penelitian yang dilakukan, yaitu:

1. Menentukan judul penelitian yang telah dikonsultasikan kepada dosen pembimbing.

2. Menyusun proposal yang terdiri dari tiga bab berdasarkan literatur dari berbagai sumber, studi pendahuluan, dan penelitian lain yang terkait dengan proposal penelitian.

3. Menentukan jenis variabel tergantung dan bebas.

4. Menentukan jumlah responden yakni dua kelas mahasiswa psikologi dengan jumlah masing-masing 10 orang. 
5. Sebelum penelitian dimulai terlebih dahulu menyiapkan ruangan yang diberi aromaterapi selama kurang lebih 30 menit.

6. Penulis memberikan lembar persetujuan pada setiap mahasiswa psikologi semester tiga di Universitas Muhammadiyah Kalimantan Timur.

7. Penulis mengukur stres setiap responden dengan mengisi lembar kuesioner Depression Anxiety Stress Scale (DASS) pada pengukuran Pre-test selama lima menit.

8. Setelah pengukuran stres, penulis melakukan intervensi Aromaterapi selama 60 menit.

9. Setelah itu dilakukan intervensi kepada responden dengan melakukan pengukuran stres kembali pasca tes menggunakan skala yang sama yaitu Depression Anxiety Stres Scale (DASS).

10. Hal yang sama diberikan kepada kelompok lain dari poin sembilan.

11. Pembuatan laporan penelitian segera dilaksanakan setelah data terkumpul.

12. Data yang terkumpul lalu dianalisis secara statistik.

\section{Teknik Pengumpulan Data}

Skala yang digunakan ialah Self Rating Scale yakni berupa pernyataan yang disampaikan oleh responden terkait tingkat stres yang dimiliki. Data pada kuesioner dideskripsikan dengan pernyataan dan pilihan lima jawaban untuk mewakili perasaan yang dirasakan oleh responden. Untuk pilihan bergerak dari Sangat Tidak Sesuai (1), Tidak Sesuai (2), Netral (3), Sesuai (4), Sangat Sesuai (5).. Skala yang digunakan dalam penelitian ini yaitu Depression Anxiety Stress Scale (DASS) dimana hasil pengukurannya menghasilkan seberapa tinggi tingkat stres yang dimiliki oleh mahasiswa.

\section{Analisis Data}

Alat ukur yang digunakan dalam penelitian ini merupakan alat ukur DASS yakni, alat ukur yang telah memiliki

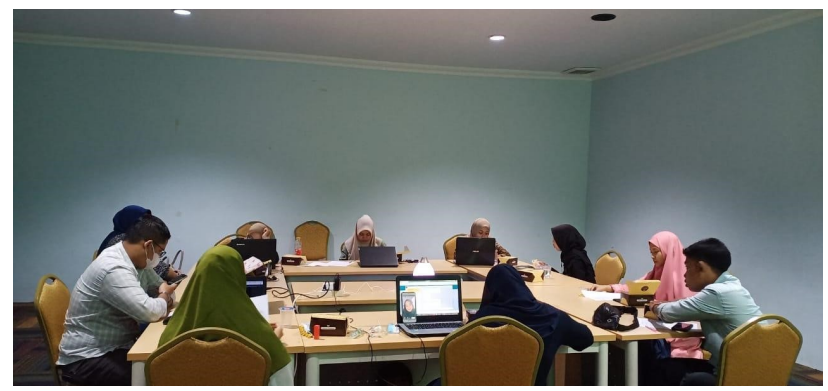

Gambar 1. Dokumentasi Proses penelitian aturan baku dan cara skoring serta norma tersendiri. Sehingga, untuk mencari perbedaan tingkat stres antara kelompok eksperimen dan kelompok kontrol dilakukan skoring secara manual dengan cara menjumlahkan skor favorable dari setiap item yakni item nomor 1,6, 8, 11, 12, 14, 18, 22, 27, 29, 32, 33, 35, 39. Pilihan jawaban bergerak dari Sangat Tidak Sesuai (1), Tidak Sesuai (2), Netral (3), Sesuai (4), Sangat Sesuai (5). Selanjutnya hasil yang didapatkan dari penjumlahan tersebut akan dikonversikan kedalam norma alat ukur DASS.

Adapun norma DASS membagi kepada lima kategori. Kategori normal adalah skor 0 hingga 14. Kategori mild adalah skor 15 hingga 18 . Kemudian kategori moderate untuk skor 19 hingga 25. Sedangkan kategori severe adalah skor 26 hingga 33 dan kategori terakhir adalah extremely severe untuk skor 34 ke atas.

\section{Hasil}

Hasil analisa data menunjukkan bahwa terdapat dua kelompok masalah mental yang dimiliki oleh subjek screening, yakni masalah gejala depresi dan kecemasan. Kelompok tersebut menghasilkan skor dengan tingkatan yang berbeda-beda hingga akhirnya diketahui hasil skor tingkat stres dari masing-masing subjek. Berdasarkan hasil tersebut juga dapat terlihat bahwa beberapa mahasiswa yang mengikuti proses screening memiliki tingkat stres yang cukup signifikan untuk melanjutkan ke tahap pemberian perlakuan. Adapun jumlah subjek penelitian setelah proses screening dilakukan adalah sebanyak 22 orang dengan 13 orang memiliki tingkatan stres moderate, 6 orang dengan tingkatan severe, dan 3 orang dengan tingkatan extreme. Subjek dipilih berdasarkan kriteria dan tujuan penelitian, sehingga penulis dapat melihat keefektivitasan perlakuan sebelum dan sesudah diberikan.

Selama penelitian berlangsung, subjek yang mengikuti proses penelitian hingga akhir yakni sebanyak 18 dari 22 orang yang sebelumnya lolos proses screening. Sehingga di dalam penelitian ini penulis membagi subjek penelitian

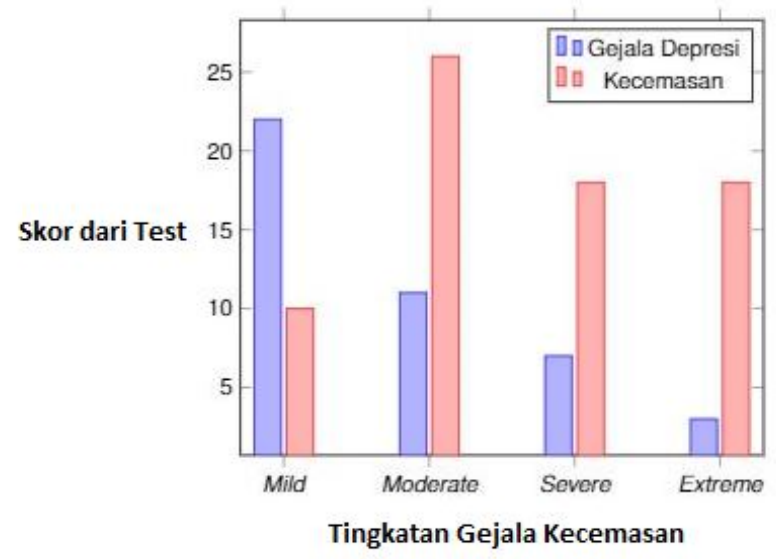

Gambar 2. Skor Pre-Test Screening 
menjadi dua kelompok yakni kelompok kontrol dan kelompok eksperimen dengan jumlah subjek penelitian sebanyak 9 orang pada masing-masing kelompok. Adapun hasil pre-test dan post-test tingkat stres pada masingmasing kelompok dijelaskan di dalam tabel di bawah ini:

Berdasarkan hasil post-test tersebut di atas dapat terlihat bahwa tingkat stres mahasiswa yang berada di kelompok eksperimen memiliki skor yang berbeda cukup signifikan dibandingkan dengan kelompok kontrol. Pada kategori stres normal terdapat perubahan yang signifikan dari kelompok eksperimen dengan kelompok kontrol. Hal ini dapat terjadi sebagai pembuktian keefektifitasan alat eksperimen. Selain itu pada tahap evaluasi akhir penulis melakukan wawancara lebih lanjut untuk mencari informasi lebih lanjut kepada mahasiswa yang ada di kelompok eksperimen terkait perubahan data yang tidak begitu signifikan. Beberapa subjek di kelompok kontrol mengatakan bahwa suhu ruangan menjadi faktor lain mengapa kondisi ruangan intervensi menjadi kurang kondusif sehingga mengganggu fokus saat mengerjakan ujian. Selain itu, hasil wawancara lain juga menyebutkan bahwa aroma yang menyengat dari minyak aroma terapi mengganggu konsentrasi saat mengerjakan ujian. Halhal merupakan kondisi yang kurang diperhatikan juga oleh penulis saat pelaksanaan intervensi yang kedepannya dapat menjadi evaluasi dan saran pengembangan intervensi aroma terapi.

\section{Diskusi}

Hasil penelitian yang dijelaskan di atas menunjukan bahwa penggunaan aromaterapi dapat menurunkan tingkat stres pada mahasiswa UMKT. Hasil ini sejalan dengan penelitian sebelumnya yang menyebutkan bahwa aromaterapi terutama aroma lavender memiliki kemampuan meningkatkan kualitas tidur, menurunkan kecemasan, dan menurunkan tingkat stres. Intervensi yang murah dan mudah diterapkan ini telah membantu pasien-pasien di rumah sakit yang memiliki masalah psikologis tersebut (Karadag et al., 2015).

Pada dasarnya aromaterapi diketahui dapat menenangkan sistem saraf pusat sehingga mampu menghilangkan ketegangan di tubuh seseorang. Sehingga pada proses penelitian ini dibutuhkan subjek yang benar-benar sedang merasakan ketegangan tersebut akibat stres dalam menghadapi ujian nantinya. Ketegangan yang berlebih dan benar-benar terasa dimiliki oleh orang-orang yang tingkat stresnya lebih tinggi dari orang lain, sehingga dibutuhkan alat bantuan seperti aromaterapi untuk meredakan stres tersebut (Karadag et al., 2015).

Aromaterapi memiliki respon psikologis dan fisiologis yang baik, terbukti dari beberapa aspek di dalam tubuh berubah setelah diberi paparan aromaterapi. Beberapa aspek tersebut yakni indeks stres, aktivitas saraf simpatik, kadar kortisol serum, dan tekanan darah. Aspek ini telah diukur pada 95 individu yang memiliki tingkatan stres yang cukup tinggi, sehingga setelah dilakukan intervensi tingkatan stres tersebut berangsur menurun (Bae et al., 2018).

Penggunaan aromaterapi telah banyak diterapkan oleh masyarakat pada umumnya saat ini. Menurut ilmuwan, aromaterapi dapat menembus ke tubuh manusia dan bereaksi secara nyata untuk memperbaiki beberapa kerusakan-kerusakan dan mengatasi berbagai masalah seperti depresi, stres, insomnia, masalah pernapasan, penyakit kulit, sendi bengkak, dll. Sehingga wajar bagi beberapa masyarakat yang memahami hal ini untuk terus mengaplikasikan aromaterapi di dalam kehidupannya sebagai bentuk mengurangi masalah yang dimiliki (Ali et al., 2015).

Stres merupakan fenomena yang tidak bisa dihindari dalam semua aspek kehidupan manusia terutama mahasiswa. Stres adalah ketidakseimbangan emosi yang terjadi karena berbagai alasan, salah satunya seperti kegiatan ujian bagi mahasiswa. Sebenarnya penyebab stres atau stressor dapat berakibat negatif maupun positif bagi individu, tergantung pada kepribadian dan cara individu dalam mengelola stress tersebut. Namun pada mahasiswa stres yang negatif justru akan sangat mempengaruhi hasil akademis, sosial, fisik, dan emosionalnya (Rana et al., 2019).

Stres yang dibahas erat kaitannya dengan stres akademik yang dirasakan mahasiswa saat ujian. Beberapa penelitian dan penelitian menyebutkan bahwa masih banyak siswa atau mahasiswa yang seringkali memiliki gejala stres yang berlebih dalam menghadapi ujian, Hal ini dapat disebabkan oleh beberapa hal yakni ketidak siapan mereka dalam menghadapi ujian, atau pernah mendengar sesuatu yang menakutkan terkait ujian yang akan dijalani. Oleh karenanya siswa atau mahasiswa merasakan ketegangan dan stres yang berlebih tersebut. Namun pada dasarnya gejala stres dapat dijadikan siswa atau mahasiswa sebagai pendorong dalam proses belajar hingga mencapai kesuksesan menjalani ujian. Sehingga stres tidak serta merta selalu dianggap sebagai hal yang merugikan saja (Kumari \& Jain, 2014).

Selanjutnya setelah dilakukan eksperimen, eksperimenter atau pengabdi melakukan wawancara terhadap beberapa subjek kelompok eksperimen yang tidak mengalami perubahan setelah diberikan intervensi tersebut. Subjek WJ mengatakan bahwa gangguan terjadi pada suhu ruangan terlalu dingin sehingga sedikit mempengaruhi keadaan saat mengerjakan ujian di ruangan tersebut, subjek AM mengatakan merasa terganggu dengan suara instrumen yang diberikan dan subjek DP mengatakan merasa aroma yang diberikan terlalu menyengat sehingga mengganggu kenyamanan saat ujian. Hasil wawancara tersebut dapat menjadi perhatian lebih untuk kedepannya dan menjadi evaluasi bagi pengabdi.

Adapun berdasarkan hasil akhir penelitian dan hasil wawancara yang telah dijelaskan di atas, diketahui bahwa terdapat keterbatasan terkait kegiatan penelitian ini. Hal tersebut ialah kurang terkontrolnya keadaan lingkungan/ruangan eksperimen yang ternyata dapat mengganggu jalannya eksperimen, dan bahkan mempengaruhi hasil 
yang ditimbulkan dari eksperimen tersebut. Selain itu kurang terjalinnya kontak antar subjek dengan pengabdi atau eksperimenter selama proses pre-eksperimen hingga pada saat eksperimen membuat berkurangnya total subjek dari yang seharusnya. Hal-hal yang disebutkan di atas dapat dijadikan sebuah makna atau pembelajaran apabila eksperimenter atau bahkan pembaca yang ingin melakukan kembali dan mengembangkan hasil penelitian ini.

\section{Kesimpulan}

Pada kegiatan penelitian ini, pengabdi telah melakukan hal-hal seperti penyebaran skala untuk screening dan pretest, hingga menentukan subjek penelitian yang dapat digunakan. Subjek penelitian yang digunakan berjumlah 18 orang dengan tingkat stres yang berbeda-beda, seperti moderate, severe, hingga extreme berdasarkan kriteria yang telah ditentukan. Selanjutnya, proses intervensi atau pemberian perlakuan dapat diberikan ketika mahasiswa menjalankan ujian, sehingga pengabdi menjadwalkan kegiatan di akhir bulan Juni bertepatan dengan UAS semester genap di UMKT.

Berdasarkan kegiatan penelitian yang telah dilakukan terhadap dua kelompok, yakni pada kelompok kontrol dan kelompok eksperimen. Didapatkan hasil bahwa aromatherapy dapat menurunkan tingkat stres mahasiswa yang mengerjakan ujian. Hal ini dapat terlihat dari semakin banyaknya tingkatan stres normal pada subjek setelah kegiatan eksperimen dilakukan (post-test), terlebih sebelumnya diketahui bahwa tingkat stres subjek banyak terbagi pada tingkatan mild, moderate, severe, bahkan extreme.

Berdasarkan hasil tersebut di atas, pengabdi atau eksperimenter juga menemukan beberapa keterbatasan kegiatan eksperimen, yakni terkait kurang terkontrolnya keadaan lingkungan atau ruang eksperimen, serta terkait jumlah subjek penelitian yang berubah dari awal pre-test hingga proses eksperimen berlangsung.

Implikasi dalam proses kegiatan penelitian ini adalah agar mahasiswa dapat menemukan alternatif cara untuk mengatasi stres yang sering terjadi ketika mengerjakan ujian, terutama pada masa pandemi covid-19 ini. Ketika mahasiswa mampu mengatasi stres dengan baik maka hasil atau nilai yang didapat dalam ujian tersebut juga memungkinkan untuk meningkat. Hal ini akan menjadi keuntungan tersendiri bagi mahasiswa, maupun bagi dosen yang mengajar sebagai tanda keberhasilan suatu mata kuliah.

Bagi pihak yang terlibat dengan mahasiswa, dalam hal ini adalah pihak dosen, fakultas, maupun universitas diharapkan dapat mengoptimalisasikan proses belajar mengajar terutama pada mahasiswa yang rentan mengalami stres. Hal ini dapat dilakukan dengan pengecekan rutin terhadap keadaan mental mahasiswa, maupun pemberian alternatif cara untuk mengatasi stres dari pihak terkait untuk mahasiswa.
Bagi penulis selanjutnya yang ingin melakukan atau mengembangkan kegiatan serupa, diharapkan untuk lebih mampu memonitoring seluruh kegiatan penelitian agar tidak ada hal-hal yang terlewat. Baik dari segi setting ruangan maupun monitor terhadap subjek-subjek penelitian dari awal pre-test hingga akhir post-test dilangsungkan. Selanjutnya untuk memperkaya hasil penelitian, pengabdi selanjutnya dapat mencari alternatif atau cara lain untuk mengatasi stres saat ujian selain menggunakan aromatherapy. Misalnya menggunakan cara konseling sebelum ujian, atau kegiatan menyenangkan lain yang bisa dilakukan mahasiswa.

\section{Referensi}

Adiesisa. K.P., Rismelina. D., Tazkiyah. A.Y., dkk. (2016). Filosofi dan manfaat batimung dan aromaterapi untuk mengurangi stres. Jurnal Psikostudia Universitas Mulawarman. 5(1), 1-18. Doi: http://dx.doi.org/10.30872/psikostudia.v5i1. 2275

Ali, B., Al-Wabel, N., Shams, S., Ahamad, A., Khan, S.A., \& Anwar, F. (2015). Essential oils used in aromatherapy: A systematic review. Asian Pacific Journal of Tropical Biomedicine. 5(8), 601-611. https://doi.org/10.1016/j.apjtb. 2015.05.007

Anggraini, Y.D.S. (2015). Pengaruh aromaterapi lavender terhadap stres mahasiswa tingkat akhir s1 keperawatan kelas B program A. Skripsi. Stikes Muhammadiyah Samarinda.

Ardani, T.A. (2013). Catatan ilmu kedokteran jiwa, 1st edt. Bandung: CV Karya Putra Darwati.

Bae, I, Song, J.A., Lee, M, Hur, M, (2018). Effects of aromatherapy essential oil inhalation on the stress response after exposure to noise and arithmetic subtraction stresor: randomized controlled trial. International Journal Clinical Experimental Medicine. 11(1), 275-284. www.ijcem.com/ ISSN:1940-5901/IJCEM0051785

Brunton, L.L., Lazo, J.S., Parker, K.L., (2008). Goodman \& Gilman's: The pharmacological basis of therapeutics. San Diego: The McGraw-Hill Companies.

Desmita. (2010). Psikologi perkembangan. Bandung: PT. Remaja Rosdakarya.

Firth, J. (2011). Stress in health professionals: Psychological and organisational causes and interventions. John Wiley \& Sons, New Castle, England.

Haryono, R. (2018). Pengaruh terapi kombinasi aromaterapi lavender dan dzikir terhadap penurunan stres dan tekanan darah pada penderita hipertensi. Jurnal Keperawatan Notokusumo, 6(1), 68-79. https://jurnal.stikes-notokusumo. ac.id/index.php/jkn/article/view/78

Karadag, E., Baglama, S.S., Ozden, D., Bakir, E. (2015). Effects of aromatherapy on sleep quality and anxiety of patients. British Association of Critical Care Nurses. Doi: https://doi. org/10.1111/nicc. 12198

Kozier, B., Erb, G., Berman, A., dan Snyder, S.J. (2010). Buku ajar fundamental keperawatan (Alih bahasa : Esty Wahyu ningsih, Devi yulianti, yuyun yuningsih. Dan Ana lusyana). 
Jakarta.

Kumari, A. \& Jain, J. (2014). Examination stres and anxiety: A study of college students. Global Journal of Multidisciplinary Studies, 4(1), 31-40. www.gjms.co.id/ ISSN:2348-0459.

Nurdini, K. (2009). Efektivitas konseling kognitif perilaku untuk mengelola stres akademik siswa sekolah menengah kejuruan. Skripsi. Universitas Pendidikan Indonesia Bandung.

Patel, C., Marmot, M. G., Terry, D. J., Carruthers, M., Hunt, B., \& Patel, M. (1985). Trial of relaxation in reducing coronary risk: four year follow up. British medical journal (Clinical research ed.), 290(6475), 1103-1106. https://doi. org/10.1136/bmj.290.6475.1103

Rana, A., Gulati, R., Wadhwa, V. (2019). Stress among students: An emerging issue. Integrated Journal of Social Sciences, 6(2), 44-48. http://pubs.iscience.id/ijss/ISSN:2348-0874

Robbins, Stephen P. \& Coulter, M. (2010). Manajemen edisi kesepuluh. Jakarta: Erlangga.

Ross, S.E., Niebling, B.C., \& Heckert, T.M. (1999). Sources of stress among college students. College student journal, 33, 312-317.

Sarafino, E.P., Timothy, \& W. Smith. (2011). Health psychology biopsychosocial interactions seventh edition. USA: John Wiley \& Sons.
Sangwin, M.J., (2016). A study on stress and aromatherapy intervention efficacy. Thesis. Department Chair Health and Human Performance, Davidson Honors College University of Montana Missoula, MT.

Sharma. S. (2009). Aroma therapy. Jakarta: Kharisma Publishing Group.

Sya'diyah, Hidayatus, Apriliani, Ratna. D. (2017). Pengaruh aromaterapi lavender terhadap penurunan tingkat stress pada lansia di Panti Werdha Anugerah Surabaya. Article Research. Stikes Hangtuah Surabaya.

Taylor, D.A. (2006). Social penetration: The development of interpersonal relationships. New York: Holt, Rinehart \& Winston.

Widayani, N.K.T., Sutrisno., \& Riniasih. W. (2016). Pengaruh aromaterapi dupa lavender terhadap penurunan tingkat stres saat penyusunan skripsi pada mahasiswa S1 keperawatan Stikes An Nur Purwodadi. Skripsi. STIKES An Nur Purwodadi.

Yusuf, S. (2006). Psikologi perkembangan anak dan remaja. Bandung: PT. Remaja Rosdakarya. 